\title{
Effective Removal of Hexavalent Chromium from Aqueous Solutions Using lonic Liquid Modified Graphene Oxide Sorbent
}

\author{
A. Nasrollahpour, ${ }^{a}$ S. E. Moradi, ${ }^{a,{ }^{*}}$ and J. Khodaveisi ${ }^{\mathrm{b}}$ \\ ${ }^{a}$ Young Researchers and Elite Club, Sari Branch, \\ Islamic Azad University, Sari, Iran \\ ${ }^{b}$ Department of Science, Sari Branch, \\ Islamic Azad University, Sari, Iran
}

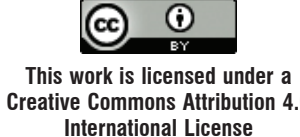

International License

Ionic liquid modified reduced graphene oxide (IL-rGO) was prepared and examined for chromate removal. The sorbent was characterized by $\mathrm{N}_{2}$ adsorption-desorption measurement (BET), transmission electron microscopy (TEM), powder X-ray diffraction (XRD), and X-ray photoelectron spectroscopy (XPS) analysis. The sorption behavior of chromate on the ionic liquid modified reduced graphene oxide sorbent from an aqueous medium was studied by varying the parameters such as contact time, initial chromate concentration, $\mathrm{pH}$, and agitation speed. The results showed that sorption kinetics of chromate by IL-rGO follows the pseudo second order, which indicates that the sorption mechanism is both chemical and physical interaction. The sorption isotherm studies revealed that Langmuir model provided the best fit to all the experimental data with an adsorption capacity of $232.55 \mathrm{mg} \mathrm{g}^{-1}$ for IL-rGO. Thermodynamic parameters, such as Gibbs free energy $\left(-2.85 \mathrm{~kJ} \mathrm{~mol}^{-1}\right.$ at $\left.298 \mathrm{~K}\right)$, enthalpy $\left(55.41 \mathrm{~kJ} \mathrm{~mol}^{-1}\right)$, and entropy (11.64 $\mathrm{J} \mathrm{mol}^{-1} \mathrm{~K}^{-1}$ ) of sorption of the chromate on ionic liquid modified reduced graphene oxide was evaluated, and it was found that the reaction was spontaneous and endothermic in nature.

Key words:

Langmuir isotherm, ionic liquid, reduced graphene oxide, chromate, removal

\section{Introduction}

Chromium is one of the heavy metals present in toxic effluents released by the aerospace, electroplating, leather, mining, dyeing, fertilizer, and photography industries ${ }^{1,2}$. The $\mathrm{Cr}(\mathrm{VI})$ ion generally exists in the form of extremely soluble and highly toxic chromate ions $\left(\mathrm{HCrO}_{4}^{-}\right.$or $\left.\mathrm{Cr}_{2} \mathrm{O}_{7}^{2-}\right)$, which can transfer freely to the biotic organisms prevailing in the aquatic ecosystem and food chain ${ }^{3}$. Therefore, the presence of chromium in the environment has received considerable attention. It has been found that chromium has a severe carcinogenic effect on human health, and causes cancer in the digestive system and lungs, and it may lead to other severe health hazards, such as dermatitis, bronchitis, perforation of the nasal septum ${ }^{4,5}$. Hence, the World Health Organization (WHO) and the United States Environmental Protection Agency (USEPA) have set a guideline for the maximum acceptable concentrations of 50 and $100 \mu \mathrm{g} \mathrm{L}^{-1}$ for total chromium in drinking water, respectively ${ }^{6}$. However, $\mathrm{Cr}(\mathrm{VI})$ concentrations in $\mathrm{Cr}(\mathrm{VI})$-bearing wastewater and $\mathrm{Cr}(\mathrm{VI})$-contaminated natural water resources are far

${ }^{*}$ Corresponding author. Fax: +98 11 33343168;

email: er moradi@hotmail.com (S. E. Moradi). above the permitted threshold level. Therefore, it is imperative to develop new materials and effective methods for $\mathrm{Cr}(\mathrm{VI})$ remediation.

The techniques used for pollutant removal from wastewater include photodegradation ${ }^{7-25}$, adsorption $^{24,26-45}$, electrocoagulation ${ }^{46,47}$, membrane filtration $^{48,49}$, and reverse osmosis ${ }^{48}$. Among these methods, sorption has proved to be an attractive process because of its low cost and ease of operation. The sorption and removal of $\mathrm{Cr}(\mathrm{VI})$ has been investigated using several sorbents, including multi-walled carbon nanotubes ${ }^{50}, \mathrm{Fe}_{3} \mathrm{O}_{4}$ nanoparticles ${ }^{51}$, resin ${ }^{52}$, clays $^{53}$, activated carbon ${ }^{54}$, and surface-modified carbon materials ${ }^{55}$. However, there is still an increasing demand for the development of efficient and cost-effective treatment technologies for the removal of $\mathrm{Cr}(\mathrm{VI})$.

Graphene oxide, a 2D carbon material, has unique physical and chemical properties which make it an ideal candidate for extended applications such as: nanoelectronics ${ }^{56}$, supercapacitors ${ }^{57}$, sensors $^{58}$, hydrogen storage ${ }^{59}$, and drug delivery ${ }^{60}$. Graphene has become a sparkling rising star on the horizon of materials science due to its extraordinary electrical, thermal, and mechanical properties ${ }^{59}$. Graphene has a large theoretical specific surface 
area of about $2.6 \cdot 10^{3} \mathrm{~m}^{2} \mathrm{~g}^{-1}$, high thermal conductivity $\left(3 \cdot 10^{3} \mathrm{~W} \mathrm{~m}^{-1} \mathrm{~K}^{-1}\right)$, and Young's modulus $\left(1.06 \cdot 10^{3} \mathrm{GPa}\right)^{57}$. Recent research has indicated that graphene oxides and chemically modified graphene oxides have proved to be promising materials for the adsorption of metal ions due to their extraordinary mechanical strength and relatively large specific area ${ }^{61}$.

Ionic liquids (ILs) have been recently gaining widespread recognition from both research and industrial applications, such as electrochemistry, extraction, organic synthesis and catalysis for clean technology and polymerization processes ${ }^{62-64}$. This is due to their unusual properties and great potential as "green" solvents for industrial processes. Moreover, they are nonvolatile, nonflammable, thermally stable, and recyclable. However, the advantageous liquid state in most cases hinders the development of ILs in applications requiring solid shape. One way to circumvent this problem is loading ionic liquids on the surface of nanomaterials ${ }^{63}$.

In this study, reduced graphene oxide has been synthesized and modified with ionic liquid. Investigated and compared were the mechanism, isotherms, thermodynamics and kinetics of sorption of chromate by graphene oxide, reduced graphene oxide, and ionic liquid modified reduced graphene oxide. The sorption capacity and kinetics were studied using the batch method. The variables affecting the sorption process, including the agitation speed, contact time, initial concentration of chromate, solution $\mathrm{pH}$, ionic strength, and temperature were optimized.

\section{Experimental}

\section{Materials}

Graphite powder ( $<20$ micron) was purchased from Sigma-Aldrich, USA and used as received. $\mathrm{H}_{2} \mathrm{SO}_{4}\left(>99 \%\right.$ ), hydrochloric acid (AR grade), $\mathrm{H}_{2} \mathrm{O}_{2}$ $(30 \%(\mathrm{w} / \mathrm{v})), \mathrm{KMnO}_{4}(>99 \%)$, ammonia solution ( $\left.>99 \%, \mathrm{NH}_{4} \mathrm{OH}\right)$, 1-butyl-3-methylimidazolium chloride ( $\left.>99 \%, \mathrm{C}_{8} \mathrm{H}_{15} \mathrm{ClN}_{2}\right)$, and cysteine $(>99 \%$, $\mathrm{C}_{3} \mathrm{H}_{7} \mathrm{NO}_{2} \mathrm{~S}$ ) were all purchased from Sigma-Aldrich (St. Louis, MO, USA).

\section{Instrumentation}

The structures of the synthesized graphene oxide, reduced graphene oxide, and ionic liquid modified reduced graphene oxide were analyzed by powder X-ray diffraction (XRD), Philips 1830 diffractometer, using graphite monochromated $\mathrm{Cu}$ $\mathrm{K} \alpha$ radiation. X-ray photoemission spectroscopy (XPS) spectra were obtained with a Scienta ESCA 200 analyzer (Gammadata, Sweden) using monochromatized $\mathrm{Cu} \mathrm{K} \alpha$ X-ray source. Adsorption-desorption isotherms of the synthesized samples were measured at $77 \mathrm{~K}$ on micromeritics model ASAP 2010 sorptometer to determine an average pore diameter. Pore-size distributions were calculated by the Barrett-Joyner-Halenda (BJH) method, while surface area of the sample was measured by the Brunauer-Emmet-Teller (BET) method. Transmission electron microscope (TEM) analysis was carried out with a JEOL JEM 2100 transmission electron microscope at $200 \mathrm{kV}$. The $\mathrm{Cr}(\mathrm{VI})$ concentration in the water was monitored by measuring the absorbance using an UV-vis spectrophotometer (CE 2501, CECIL instruments, Cambridge, UK) with $1.0 \mathrm{~cm}$ glass cuvettes at $517 \mathrm{~nm}$. The $\mathrm{pH}$ of solutions was determined with a Metrohm $780 \mathrm{pH}$ meter equipped with a combined glass calomel electrode (Metrohm Co., Herisau, Switzerland).

\section{Synthesis of IL-rGO}

Ionic liquid modified reduced graphene oxide was obtained by the method as described by Wang et. al. ${ }^{65} \mathrm{In}$ a typical synthesis, $0.5 \mathrm{~g}$ of the ionic liquid ([Bmim][Cys]) was put into $10 \mathrm{~mL} \mathrm{GO}$ aqueous suspension of $0.5 \mathrm{mg} \mathrm{mL}^{-1}$. The mixture was kept in a tightly sealed glass bottle, and stirred for $15 \mathrm{~h}$ at room temperature. Firstly, the black product was isolated by centrifugation at $8000 \mathrm{rpm}$, and then the obtained black slurry was washed with deionized water. One part of the as-prepared products was then dispersed in deionized water to prepare the suspension of IL-rGO, and the other part was used to produce the powder of IL-rGO by drying at 50 ${ }^{\circ} \mathrm{C}$ for $24 \mathrm{~h}$ under vacuum.

\section{Batch sorption procedure}

The sorption equilibrium studies of graphene oxide, reduced graphene oxide, and ionic liquid modified reduced graphene oxide for chromate were conducted with $50 \mathrm{~mL}$ of a $\mathrm{Cr}(\mathrm{VI})$ solution $\left(200 \mathrm{mg} \mathrm{L}^{-1}\right.$ ) and $0.5 \mathrm{~g} \mathrm{~L}^{-1}$ of the sorbent at $298 \mathrm{~K}$, unless otherwise stated. The sorbent and sorbate was mixed on a shaking bath at $250 \mathrm{rpm}$ until equilibrium was attained (typically in 5 hours). After the sorption was complete, the mixture of sorbent and sorbate was centrifuged at $3000 \mathrm{rpm}$ for 3 minutes, and the amount of $\mathrm{Cr}(\mathrm{VI})$ remaining in the solution was determined by measuring its absorbance at 517 $\mathrm{nm}$ with a UV-Vis spectrophotometer. The amount of $\mathrm{Cr}(\mathrm{VI})$ sorbed on the sorbent was determined as follows:

$$
q_{\mathrm{e}}=\frac{\left(C_{0}-C_{\mathrm{e}}\right) V}{W}
$$

where $q_{\mathrm{e}}$ is the amount of $\mathrm{Cr}(\mathrm{VI})$ sorbed by the sorbent ( $\mathrm{mg}$ of $\mathrm{Cr}(\mathrm{VI}) / \mathrm{g}$ of the sorbent), $C_{0}$ and $C_{\mathrm{e}}$ are the $\mathrm{Cr}(\mathrm{VI})$ concentrations $\left(\mathrm{mg} \mathrm{L}^{-1}\right)$ at time 0 and equilibrium, respectively, $V$ is the volume of the solution (L), and $W$ is the mass of the sorbent (g). Each experiment was conducted three times, and 
the average and standard deviation of the results were determined.

The kinetic studies for all the five sorbents were carried out with $250 \mathrm{mg} \mathrm{L}^{-1}$ of $\mathrm{Cr}(\mathrm{VI})$ at $\mathrm{pH}$ 4.0. For such studies, a series of $50 \mathrm{~mL}$ of the $\mathrm{Cr}(\mathrm{VI})$ solution was added to $25 \mathrm{mg}$ of the sorbent. The samples were shaken at $298 \mathrm{~K}$ and $250 \mathrm{rpm}$. The experimental data were analyzed by the most commonly used models of pseudo first-order and pseudo second-order.

\section{Results and discussion}

\section{Textural characterization}

The nitrogen adsorption-desorption isotherms of reduced graphene oxide and ionic liquid modified reduced graphene oxide samples are shown in Figure 1. The nitrogen adsorption-desorption isotherms of graphene oxide, reduced graphene oxide, and ionic liquid modified reduced graphene oxide show a type IV isotherm according to IUPAC classification, corresponding to mesoporous solids. The specific surface area $\left(S_{\mathrm{BET}}\right)$ and specific volume of the rGO are $2302 \mathrm{~m}^{2} \mathrm{~g}^{-1}$ and $0.88 \mathrm{~cm}^{3} \mathrm{~g}^{-1}$, respectively. The specific surface area and specific volume of IL-rGO are reduced to $1454 \mathrm{~m}^{2} \mathrm{~g}^{-1}$ and 0.62 $\mathrm{cm}^{3} \mathrm{~g}^{-1}$, respectively. Therefore, it may be assumed that ionic liquids are located inside the pores or near the pore opening of reduced graphene oxide.

The XRD patterns of graphene oxide, reduced graphene oxide, and ionic liquid modified reduced graphene oxide are presented in Figure 2. Comparison of XRD pattern of IL-rGO and rGO with GO, suggested that the basal spacing between the (002) planes increased from $0.35 \mathrm{~nm}$ to about $0.8 \mathrm{~nm}$, which was signified by a new broad peak at $2 \theta=11.8^{\circ}$ replacing the peak at $2 \theta=25.4^{\circ}$. This revealed that IL-rGO, rGO, and GO were well modified and had the representative peaks of IL-rGO, rGO, and GO.

The chemical state of the carbon of the GO, rGO, and IL-rGO was examined by the XPS technique (Figure 3). The C1s XPS spectrum of GO shows that, beside the band of aromatic $\mathrm{C}-\mathrm{C}$ bonds at $\mathrm{BE}=284.6 \mathrm{eV}$, there is a very broad peak ranging from 286 to $290 \mathrm{eV}$, indicating a considerable degree of oxidation and the presence of different oxygen-containing groups. However, C1s XPS spectra of IL-rGO show almost identical features with that of rGO, which demonstrate the aromatic nature of graphene-like material. The broadened peak shape of reduced graphene oxide and ionic liquid modified reduced graphene oxide indicates that these materials have a much more disordered structure than graphite.

The structure of the IL-rGO was further studied by transmission electron microscopy (TEM) (Figure

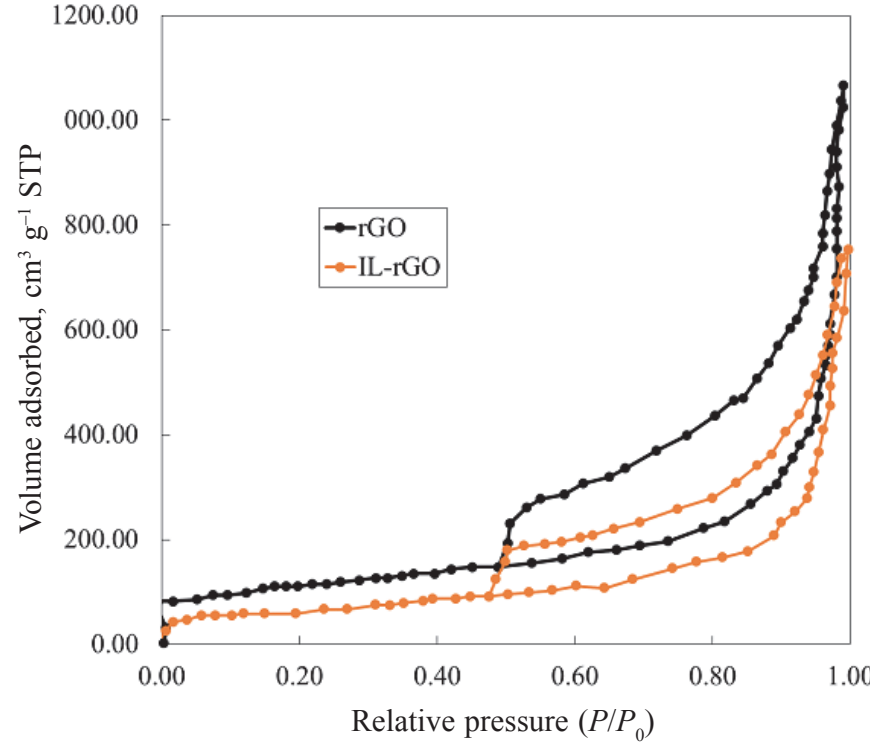

Fig. $1-N$, sorption isotherms of graphene oxide, reduced graphene oxide, and ionic liquid modified reduced graphene oxide samples measured at $77 \mathrm{~K}$

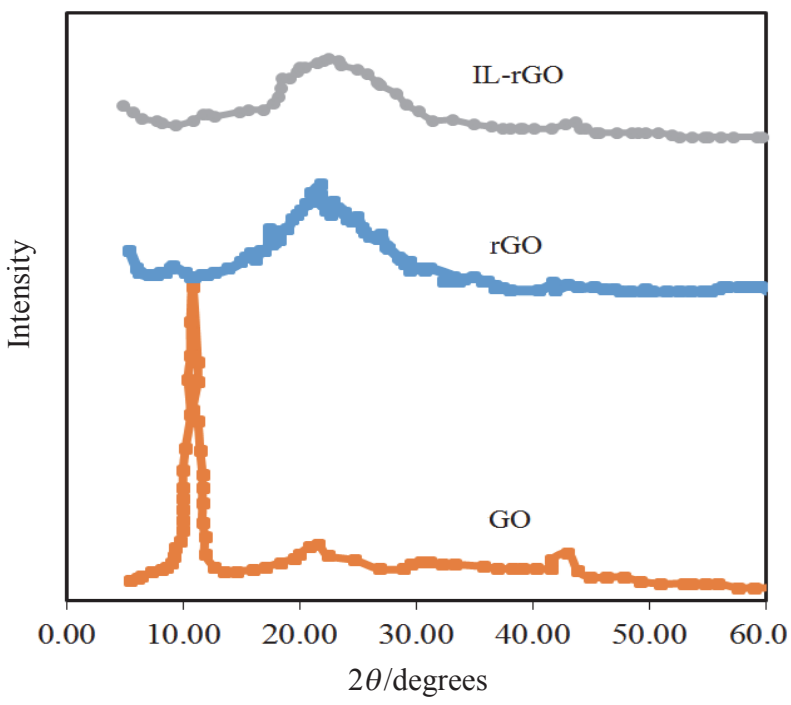

Fig. 2 - XRD patterns of graphene oxide, reduced graphene oxide, and ionic liquid modified reduced graphene oxide samples

4). The TEM image proves that IL-rGO hybrid material is formed and ionic liquids are well dispersed on the surface of reduced graphene oxide.

\section{Influence of contact time and initial concentration on $\mathrm{Cr}(\mathrm{VI})$ removal}

The influence of contact time on Cr(VI) sorption by graphene oxide, reduced graphene oxide, and ionic liquid modified reduced graphene oxide sorbents were studied (Figure 5). The results showed that the sorption capacity increased with time and reached a constant value after $5 \mathrm{~h}$. Thus, an optimum contact time of $5 \mathrm{~h}$ was selected for further studies. 


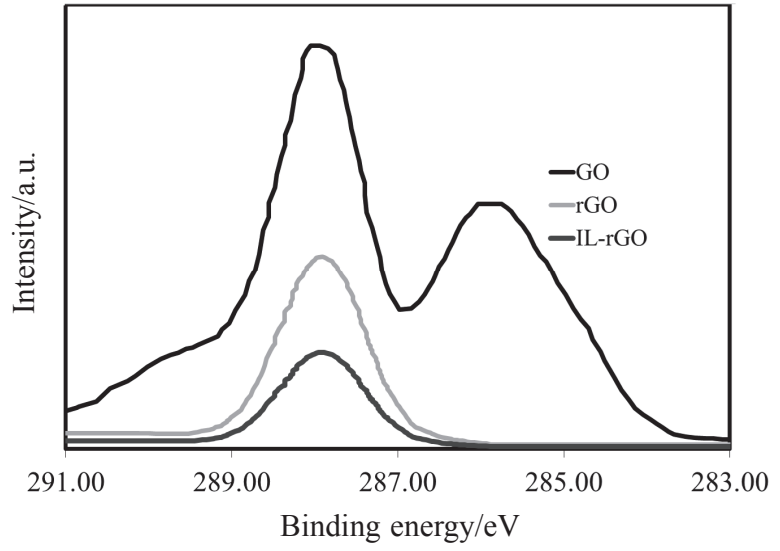

Fig. 3 - XPS patterns of graphene oxide, reduced graphene oxide, and ionic liquid modified reduced graphene oxide samples

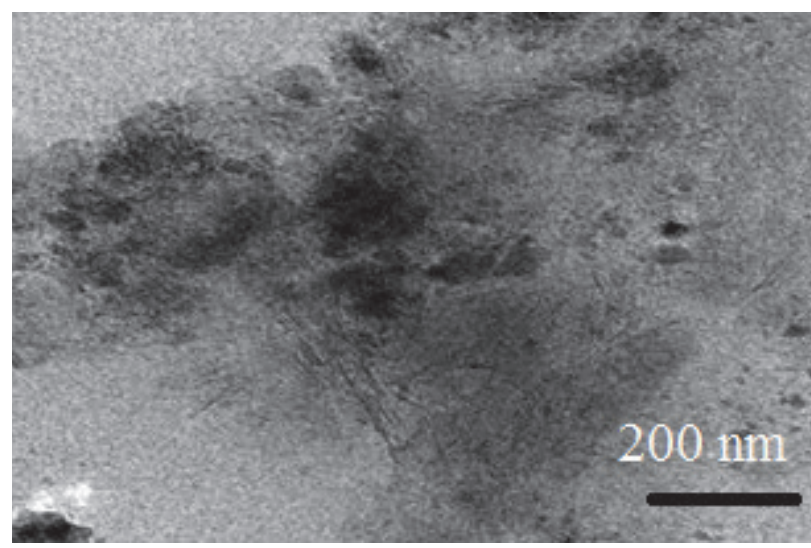

Fig. 4-TEM image of ionic liquid modified reduced graphene oxide sample

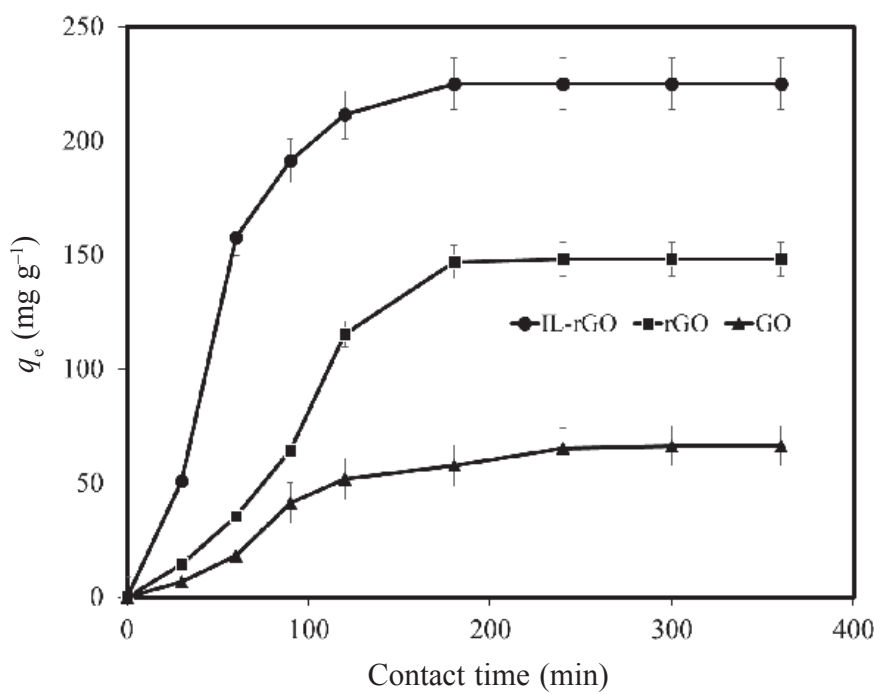

Fig. 5 - Effect of contact time on the sorption of $\mathrm{Cr}(\mathrm{VI})$ on $I L-r G O, r G O$, and $G O$ (agitation speed $=250 \mathrm{rpm},[\mathrm{Cr}(\mathrm{VI})]=$ $200 \mathrm{mg} \mathrm{L}^{-1}$, sorbent dosage $=0.5 \mathrm{~g} \mathrm{~L}^{-1}$, temperature $=298 \mathrm{~K}$ and $\mathrm{pH}$ 4.0)

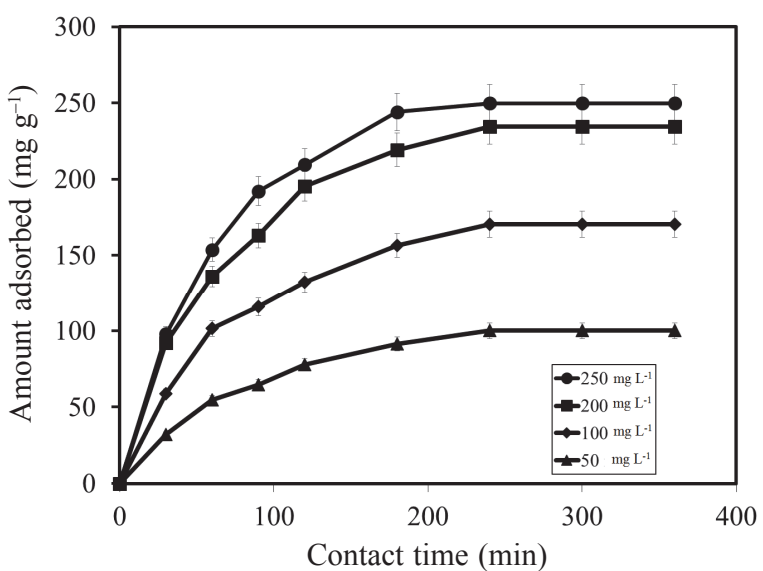

Fig. 6 - Effect of initial concentration on removal of $\mathrm{Cr}(V I)$ by IL-rGO (agitation speed $=250 \mathrm{rpm}$, contact time $=5 \mathrm{~h}$, sorbent dosage $=0.5 \mathrm{~g} \mathrm{~L}^{-1}$, temperature $=298 \mathrm{~K}$ and $\mathrm{pH} 4.0$ )

The effect of chromate ion initial concentration on its removal by IL-rGO is shown in Figure 6. The initial concentration of $\mathrm{Cr}(\mathrm{VI})$ significantly influenced the extent of $\mathrm{Cr}(\mathrm{VI})$ sorption, i.e., an increase from 50 to $250 \mathrm{mg} \mathrm{L}^{-1}$ caused a significant increase in the sorbent capacity from 91.3 to $249.4 \mathrm{mg} \mathrm{g}^{-1}$, respectively. Thus, an increase in $\mathrm{Cr}(\mathrm{VI})$ initial concentration enhances the interaction between the $\mathrm{Cr}(\mathrm{VI})$ molecules and the surface of the sorbents. Therefore, the selected optimum initial concentration of $\mathrm{Cr}(\mathrm{VI})$ was $250 \mathrm{mg} \mathrm{L}^{-1}$ for the rest of the experimental studies.

The higher sorption capacity of IL-rGO as compared to rGO and GO can be attributed to the fact that IL-rGO can interact more effectively than the other sorbent through complexation of chromate to ionic liquid.

\section{Influence of agitation speed}

The influence of agitation speed on the removal of $\mathrm{Cr}(\mathrm{VI})$ by the IL-rGO, rGO, and GO sorbents was examined by changing the agitation speed between 0 to $300 \mathrm{rpm}$, while keeping all other experimental conditions constant, as presented in Figure 7. It was found that, with a fixed stirring time, an increase in the agitation speed up to $250 \mathrm{rpm}$ caused an increase in the sorbents capacity, which leveled off at a higher speed. Thus, the agitation speed of $250 \mathrm{rpm}$ was chosen as the optimum agitation speed for all the sorption experiments.

\section{The influence of $\mathrm{pH}$}

The $\mathrm{pH}$ is a key parameter controlling the $\mathrm{Cr}(\mathrm{VI})$ sorption process. The $\mathrm{pH}$ dependence of $\mathrm{Cr}(\mathrm{VI})$ sorption can largely be related to the type and ionic state of the functional groups of the sorbent surface, as well as to the $\mathrm{Cr}(\mathrm{VI})$ chemistry in the solution. The influence of $\mathrm{pH}$ on the sorption of $\mathrm{Cr}(\mathrm{VI})$ by IL-rGO was studied by changing the $\mathrm{pH}$ 


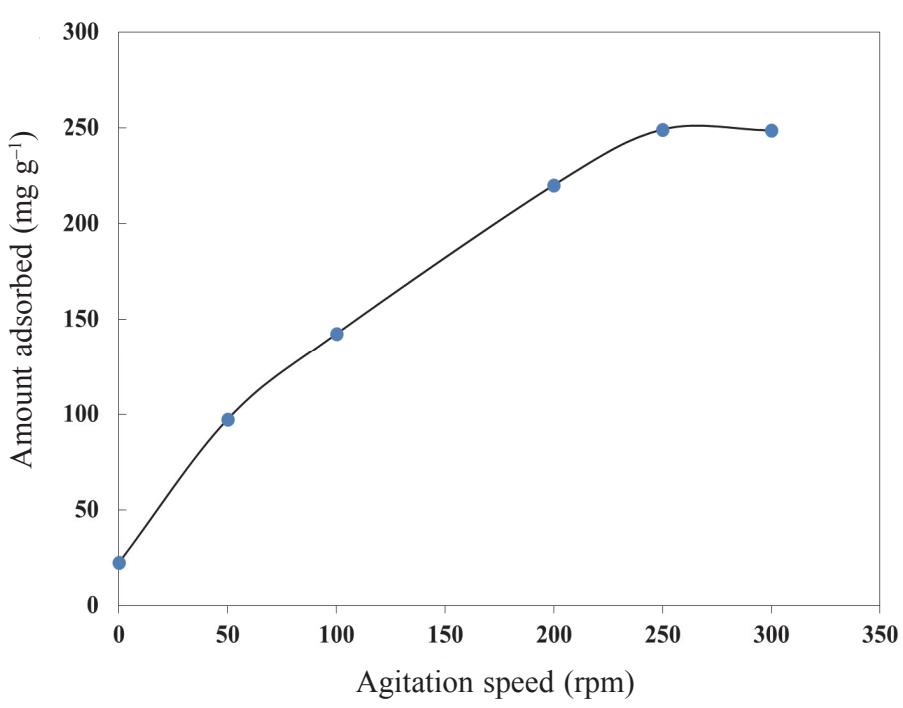

Fig. 7 - Effect of agitation speed on removal of $\mathrm{Cr}(\mathrm{VI})$ by $I L-r G O$ (sorbent dosage $=0.5 \mathrm{~g} \mathrm{~L}^{-1}$, [Cr(VI)] $=250 \mathrm{mg} \mathrm{L}^{-1}$, contact time $=5$ h, temperature $=298 \mathrm{~K}$ and $\mathrm{pH}$ 4.0)

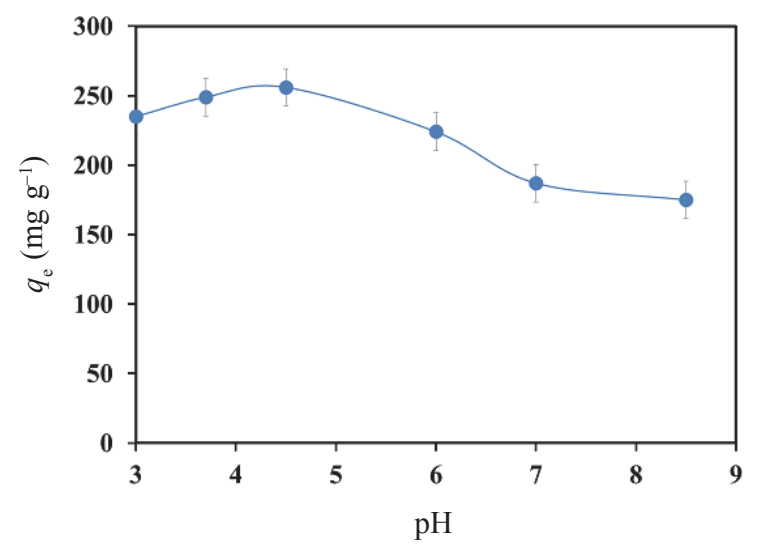

Fig. 8 - Effect of $p H$ on the sorption of Cr(VI) onto IL-rGO (sorbent dosage $=0.5 \mathrm{~g} \mathrm{~L}^{-1}$, $[\mathrm{Cr}(\mathrm{VI})]=250 \mathrm{mg} \mathrm{L} \mathrm{L}^{-1}$, contact time $=5$ h, temperature $=298 \mathrm{~K}$ and $\left.[\mathrm{Cr}(\mathrm{VI})]=250 \mathrm{mg} \mathrm{L}^{-1}\right)$

from 3.0 to 8.5. The result obtained is shown in Figure 8. As the $\mathrm{pH}$ value increased up to 3.0 , the capacity of the sorbent for removal of $\mathrm{Cr}(\mathrm{VI})$ was promoted, while the maximum removal took place in the $\mathrm{pH}$ range of 3.0-4.5. Further increase in $\mathrm{pH}$ decreased the sorption of chromium by the sorbent. The influence of $\mathrm{pH}$ observed on the sorption of chromate by the sorbent can be correlated to the $\mathrm{pH}$-regulated distribution of $\mathrm{Cr}(\mathrm{VI})$ species and the surface charge of sorbent in the specified $\mathrm{pH}$ range. Maximum chromium sorption at $\mathrm{pH} 4.5$ seems to be due to a net positive charge on IL-rGO surface at low $\mathrm{pH}$. At low $\mathrm{pH}$ values, the dominant species of $\mathrm{Cr}(\mathrm{VI})$ in solution is $\mathrm{HCrO}_{4}^{-}$. Therefore, $\mathrm{HCrO}_{4}^{-}$ easily adsorbed to the surface of positive sorbents at lower $\mathrm{pH}$ values. Moreover, at higher $\mathrm{pH}$ values, $\mathrm{OH}^{-}$and $\mathrm{Cr}(\mathrm{VI})$ species $\left(\mathrm{CrO}_{4}{ }^{2-}\right.$ and $\left.\mathrm{Cr}_{2} \mathrm{O}_{7}{ }^{2-}\right)$ compete for the same sorption site on the graphene oxide, resulting in a lower removal of $\mathrm{Cr}(\mathrm{VI})$. Thus,
Table 1 - The pseudo first order and pseudo second order kinetic constants of chromate removal by IL-rGO adsorbent at different concentrations (stirring rate $=250 \mathrm{rpm}$, sorbent dosage $=0.5 \mathrm{~g} \mathrm{~L}^{-1}$, room temperature $=298 \mathrm{~K}, \mathrm{pH} 4.0$ )

\begin{tabular}{c|c|c|c|c}
\hline \multirow{2}{*}{$\begin{array}{c}\text { Initial } \\
\text { concentration } \\
\left(\mathrm{mg} \mathrm{L}^{-1}\right)\end{array}$} & \multicolumn{2}{|c|}{$\begin{array}{c}\text { Pseudo first order } \\
\text { model }\end{array}$} & \multicolumn{2}{|c}{$\begin{array}{c}\text { Pseudo second order } \\
\text { model }\end{array}$} \\
\cline { 2 - 5 } & $k_{1}$ & $R^{2}$ & $k_{2}$ & $R^{2}$ \\
\hline 50 & 0.014 & 0.9559 & $4.24 \cdot 10^{-5}$ & 0.9977 \\
100 & 0.015 & 0.9426 & $1.77 \cdot 10^{-5}$ & 0.9962 \\
200 & 0.016 & 0.9457 & $1.75 \cdot 10^{-5}$ & 0.9974 \\
250 & 0.016 & 0.9638 & $1.72 \cdot 10^{-5}$ & 0.9966 \\
\hline
\end{tabular}

the sorption quantities of $\mathrm{Cr}(\mathrm{VI})$ at lower $\mathrm{pH}$ are larger than those at higher $\mathrm{pH}$.

\section{Kinetics of sorption}

The dynamics of the sorption procedure from an aqueous solution and the process of sorption of $\mathrm{Cr}(\mathrm{VI})$ on IL-rGO sorbent were considered through the fitness of the experimental data with various kinetic models. The kinetics data were fitted with pseudo first order (eq. 2) and pseudo second order (eq. 3) kinetic model, described as follows:

$$
\begin{gathered}
\log \left(q_{\mathrm{e}}-q_{\mathrm{t}}\right)=\log q_{\mathrm{e}}-\frac{k_{1} t}{2.303} \\
\frac{t}{q_{\mathrm{t}}}=\frac{1}{k_{2} q_{\mathrm{e}}^{2}}+\frac{t}{q_{\mathrm{e}}}
\end{gathered}
$$

where $q_{\mathrm{e}}$ and $q_{\mathrm{t}}$ are the sorption capacities at equilibrium and at time $t$, respectively, and $k_{1}$ is the pseudo first order rate constant $\left(\mathrm{min}^{-1}\right)$. The pseudo first order rate constant $\left(k_{1}\right)$, and the pseudo second order sorption $\left(k_{2}\right)$. The $k_{1}, k_{2}$ and $R^{2}$ were calculated, and are provided in Table 1 and Figure 9.

The results in Table 1 and Figure 9 clearly indicate that the pseudo second order model with high calculated linear regression correlation coefficient $\left(R^{2}\right)$ can best describe the kinetics of $\mathrm{Cr}(\mathrm{VI})$ sorption for IL-rGO sorbent. Thus, these results further support the assumption that the sorption is chemisorption. The sorption on IL-rGO can also be fitted to pseudo second order model due to its high correlation coefficient. Thus, in the case of IL-rGO, sorption occurs by both chemical and physical interactions. This observation further proves the higher sorption capacity of IL-rGO sorbent as compared to the other sorbents.

\section{Sorption isotherm}

Equilibrium sorption studies were performed to investigate the sorption capacities and mechanisms 

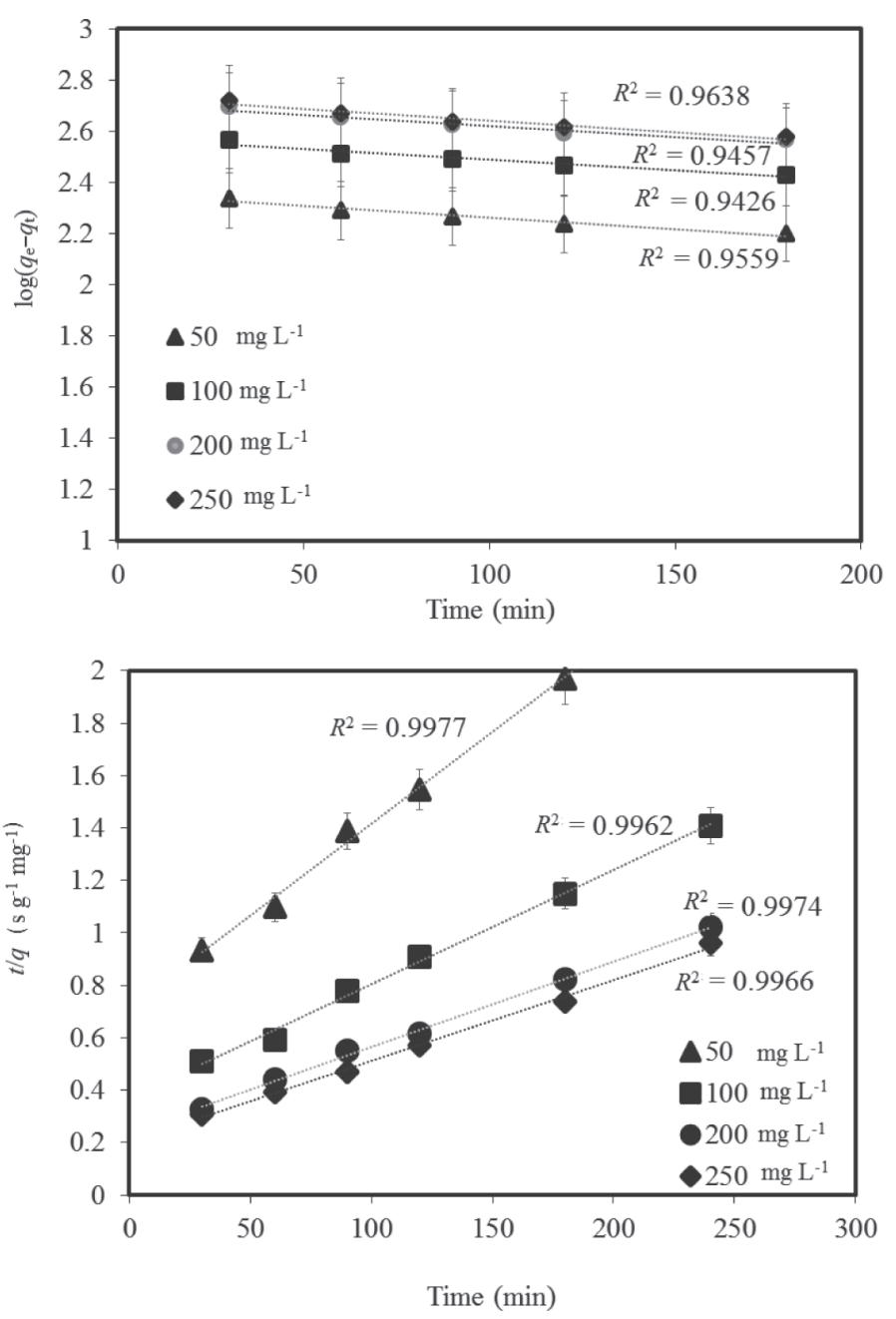

Fig. 9 - Kinetic equations (pseudo first order and pseudo second order) for chromate removal by $I L-r G O$ sorbent at different concentrations (agitation speed $=250 \mathrm{rpm}$, sorbent dosage $=0.5 \mathrm{gL}^{-1}$, room temperature $\left.=298 \mathrm{~K}, \mathrm{pH} 4.0\right)$

of IL-rGO toward Cr(VI). The uptakes of Cr(VI) on ionic liquid modified reduced graphene oxide sorbent was quantitatively evaluated using Langmuir, Temkin and Freundlich isotherms. The Freundlich sorption isotherm is presented by the following equation:

$$
\ln q_{\mathrm{e}}=\ln K_{\mathrm{f}}+\left(\frac{1}{n}\right) \ln C_{\mathrm{e}}
$$

where $K_{\mathrm{f}}$ and $n$ are Freundlich empirical constant, $C_{\mathrm{e}}$ is the $\mathrm{Cr}(\mathrm{VI})$ equilibrium concentration in the solution $\left(\mathrm{mg} \mathrm{L}^{-1}\right)$, and $q_{\mathrm{e}}$ is the equilibrium sorption capacity $\left(\mathrm{mg} \mathrm{g}^{-1}\right)$.
The Langmuir equation is presented as follows:

$$
\frac{C_{\mathrm{e}}}{q_{\mathrm{e}}}=\left(\frac{1}{q_{\mathrm{m}} b}\right)+\left(\frac{1}{q_{\mathrm{m}}}\right) C_{\mathrm{e}}
$$

where $C$ is the equilibrium liquid phase concentration of $\mathrm{Cr}(\mathrm{VI})\left(\mathrm{mg} \mathrm{L}^{-1}\right), q_{\mathrm{m}}\left(\mathrm{mg} \mathrm{g}^{-1}\right)$ is the maximum sorption capacity, $q_{\mathrm{e}}\left(\mathrm{mg} \mathrm{g}^{-1}\right)$ is the equilibrium sorption capacity, and $b$ is the Langmuir constant associated with the sorption energy.

The Temkin equation is presented as follows:

$$
\begin{gathered}
q_{\mathrm{e}}=A \ln K_{\mathrm{T}}+A \ln C_{\mathrm{e}} \\
A=\frac{R T}{b}
\end{gathered}
$$

where $A$ is the Temkin isotherm constant, $R$ is the gas constant $\left(8.314 \mathrm{~J} \mathrm{~mol}^{-1} \mathrm{~K}^{-1}\right), b$ is Temkin isotherm constant, $T$ is the temperature $(\mathrm{K})$, and $K_{\mathrm{T}}$ is the equilibrium binding constant $\left(\mathrm{mol}^{-1}\right)$ corresponding to the maximum binding energy. The coefficient of determination $\left(R^{2}\right)$ of the linearized isotherm data of the three models at $298 \mathrm{~K}$ and $\mathrm{pH}$ of $\sim 4.5$ were calculated. The results are provided in Table 2. The comparison of the correlation coefficients values of the models suggested that the Langmuir model with a higher value of correlation was best fitted to the experimental results. Furthermore, the higher $q_{\mathrm{m}}$ values for the sorption of $\mathrm{Cr}(\mathrm{VI})$ by IL-rGO (250.0 $\left.\mathrm{mg} \mathrm{g}^{-1}\right)$ indicated that its mono layer sorption capacity was very high.

\section{Thermodynamics of the sorption of $\mathrm{Cr}(\mathrm{VI})$ on sorbents}

Thermodynamic parameters including Gibbs free energy change $\left(\Delta G^{0}\right)$, enthalpy $\left(\Delta H^{0}\right)$, and entropy $\left(\Delta S^{0}\right)$ were calculated for sorption of $\mathrm{Cr}(\mathrm{VI})$ on ionic liquid modified reduced graphene oxide sorbent by varying the temperature in the range of 298-328 K under other optimized conditions (Table $3)$. As it was observed, an increase in the temperature from $298 \mathrm{~K}$ to $328 \mathrm{~K}$ caused an increase in the $\mathrm{Cr}(\mathrm{VI})$ removal by all the sorbents.

The Gibbs free energy, as well as the enthalpy process were calculated from experimental results using the following equations:

$$
\begin{gathered}
K_{\mathrm{C}}=q_{\mathrm{e}} / C_{\mathrm{e}} \\
\Delta G^{0}=-R T \ln K_{\mathrm{C}} \\
\ln K_{\mathrm{C}}=\frac{\Delta S^{0}}{R}-\frac{\Delta H^{0}}{R T}
\end{gathered}
$$

Table 2 -Temkin, Langmuir and Freundlich constants for sorption of chromate on IL-rGO sorbent

\begin{tabular}{c|c|c|c|c|c|c|c|c|c}
\hline \multirow{2}{*}{ Sorbent } & \multicolumn{3}{|c|}{ Langmuir } & \multicolumn{3}{c|}{ Freundlich } & \multicolumn{3}{c}{ Temkin } \\
\cline { 2 - 11 } & $q_{\mathrm{m}}\left(\mathrm{mg} \mathrm{g}^{-1}\right)$ & $b\left(\mathrm{~L} \mathrm{mg}^{-1}\right)$ & $R^{2}$ & $K_{\mathrm{F}}\left(\mathrm{mg} \mathrm{g}^{-1}\right)$ & $n\left(\mathrm{~L} \mathrm{mg}^{-1}\right)$ & $R^{2}$ & $K_{\mathrm{T}}$ & $A$ & $R^{2}$ \\
\hline \multirow{2}{*}{ IL-rGO } & 250.0 & 0.1176 & 0.9992 & 129.02 & 8.77 & 0.8975 & 1.23 & 114.17 & 0.9092 \\
\hline
\end{tabular}


Table 3 - Thermodynamic parameters for sorption of chromate on IL-rGO sorbent (agitation speed $=250$ rpm, sorbent dosage $=$ $0.5 \mathrm{~g} \mathrm{~L}^{-1}$, temperature $=298-328 \mathrm{~K}$ and $\left.\mathrm{pH} 6.0\right)$

\begin{tabular}{c|c|c|c|c|c|c|c}
\hline sorbent & $\begin{array}{c}T \\
(\mathrm{~K})\end{array}$ & $\begin{array}{c}C_{\mathrm{e}} \\
\left(\mathrm{mg} \mathrm{L}^{-1}\right)\end{array}$ & $\begin{array}{c}q_{\mathrm{e}} \\
\left(\mathrm{mg} \mathrm{g}^{-1}\right)\end{array}$ & $K_{\mathrm{C}}$ & $\begin{array}{c}\Delta G^{0} \\
\left(\mathrm{~kJ} \mathrm{~mol}^{-1}\right)\end{array}$ & $\begin{array}{c}\Delta H^{0} \\
\left(\mathrm{~kJ} \mathrm{~mol}^{-1}\right)\end{array}$ & $\begin{array}{c}\Delta S^{0} \\
\left(\mathrm{~J} \mathrm{~mol}^{-1} \mathrm{~K}^{-1}\right)\end{array}$ \\
\hline \multirow{2}{*}{ IL-rGO } & 298 & 77.34 & 245.30 & 3.17 & -2.85 & 55.41 & 11.64 \\
& 308 & 73.50 & 253.10 & 3.44 & -3.16 & & \\
& 318 & 67.73 & 264.53 & 3.90 & -3.60 & & \\
& 328 & 62.74 & 274.53 & 4.37 & -4.02 & \\
\hline
\end{tabular}

Table 4 - The $q_{m}$ values for the sorption of chromate on different sorbents

\begin{tabular}{lccc}
\hline \multicolumn{1}{c|}{ Sorbent } & $q_{\mathrm{m}}\left(\mathrm{mg} \mathrm{g}^{-1}\right)$ & Reference \\
\hline IL-rGO & 250.0 & This work \\
mesoporous carbon microspheres & 165.3 & 66 \\
HDTMA-zeolite & 8.8 & 67 \\
Aminated wheat straw & 245 & 68 \\
$\mathrm{Fe}_{3} \mathrm{O}_{4} \mathrm{NP}$ & 20.2 & 12 \\
Magnetotactic bacteria & 70.4 & 69 \\
\hline
\end{tabular}

where $C_{\mathrm{e}}$ is the equilibrium concentration $\left(\mathrm{mg} \mathrm{L}^{-1}\right)$ of the $\mathrm{Cr}(\mathrm{VI})$ solution, $q_{\mathrm{e}}$ is the equilibrium sorption capacity $\left(\mathrm{mg} \mathrm{g}^{-1}\right), R$ is the universal gas constant $\left(8.314 \cdot 10^{-3} \mathrm{~kJ} \mathrm{~mol}^{-1} \mathrm{~K}^{-1}\right), T$ is the temperature in Kelvin, and $K_{\mathrm{C}}$ is the equilibrium constant calculated as the surface and solution metal distribution ratio. The calculated thermodynamic parameters are listed in Table 3. As may be seen, the value of $K_{\mathrm{c}}$ increased with an increase in the temperature from 298 to $328 \mathrm{~K}$ for all sorbents, favoring the sorption of analyte. The negative value of $\Delta G^{0}$ and the positive value $\Delta H^{0}$ at different temperatures indicated that the sorption of $\mathrm{Cr}(\mathrm{VI})$ by the sorbents was spontaneous and endothermic, respectively. The positive values of $\Delta S^{0}$ suggested the increased randomness at the sorbent-solution interface during the sorption of $\mathrm{Cr}(\mathrm{VI})$ from the aqueous solution to the sorbents.

\section{Performance evaluation}

The maximum sorption capacity $\left(q_{\max }\right)$ of ILrGO for $\mathrm{Cr}(\mathrm{VI})$ was calculated by the Langmuir isotherm model and compared to the other sorbents ${ }^{51,66-69}$ with high capacity used for this purpose (Table 4). It is clear that IL-rGO has the advantages of higher sorption capacity.

\section{Conclusion}

In this study, graphene oxide, reduced graphene oxide, and ionic liquid modified reduced graphene oxide were prepared. Their structural order and tex- tural properties were studied by $\mathrm{N}_{2}$ adsorption-desorption measurement (BET), transmission electron microscopy (TEM), powder X-ray diffraction (XRD), X-ray photoelectron spectroscopy (XPS) analysis, and the potentials of these sorbents for removal of $\mathrm{Cr}(\mathrm{VI})$ were comparatively examined. The sorption kinetics of $\mathrm{Cr}(\mathrm{VI})$ by IL-rGO was found to fit the pseudo second order, indicating that the major sorption mechanism is physical. From an equilibrium study, it was found that the Langmuir model provided the best fit to the experimental data. Thus, the removal of $\mathrm{Cr}(\mathrm{VI})$ occurs through monolayer sorption. It was also found that, among the sorbents investigated for $\mathrm{Cr}(\mathrm{VI})$ removal, the IL-rGO had a higher capacity, which can be attributed to the higher sorption availability of the active sites.

\section{References}

1. Fu, F., Wang, $Q$., Removal of heavy metal ions from wastewaters: A review, J. Environ. Manage. 92 (2011) 407. doi: https://doi.org/10.1016/j.jenvman.2010.11.011

2. Chigbo, F. E., Smith, R. W., Shore, F. L., Uptake of arsenic, cadmium, lead and mercury from polluted waters by the water hyacinth Eichornia crassipes, Environ. Pollut. 27 (1982) 31 doi: https://doi.org/10.1016/0143-1471(82)90060-5

3. Huang, Z.-N., Wang, X.-L., Yang, D.-S., Adsorption of $\mathrm{Cr}(\mathrm{VI})$ in wastewater using magnetic multi-wall carbon nanotubes, Water Sci. Eng. 8 (2015) 226. doi: https://doi.org/10.1016/j.wse.2015.01.009

4. Cerveira, J. F., Sánchez-Aragó, M., Urbano, A. M., Cuezva, $J$. M., Short-term exposure of nontumorigenic human bronchial epithelial cells to carcinogenic chromium(VI) compromises their respiratory capacity and alters their bioenergetic signature, FEBS Open Bio 4 (2014) 594. doi: https://doi.org/10.1016/j.fob.2014.06.006

5. Belagyi, J., Pas, M., Raspor, P., Pesti, M., Páli, T., Effect of hexavalent chromium on eukaryotic plasma membrane studied by EPR spectroscopy, BBA BIOMEMB 1421 (1999) 175 . doi: https://doi.org/10.1016/S0005-2736(99)00129-7

6. Sandana Mala, J. G., Sujatha, D., Rose, C., Inducible chromate reductase exhibiting extracellular activity in Bacillus methylotrophicus for chromium bioremediation, Microbiol. Res. 170 (2015) 235. doi: https://doi.org/10.1016/j.micres.2014.06.001

7. Wang, Y.-S., Shen, J.-H., Horng, J.-J., Chromate enhanced visible light driven $\mathrm{TiO}_{2}$ photocatalytic mechanism on Acid 
Orange 7 photodegradation, J. Hazard. Mater. 274 (2014) 420. doi: https://doi.org/10.1016/j.jhazmat.2014.04.042

8. Gupta, V. K., Jain, R., Mittal, A., Saleh, T. A., Nayak, A., Agarwal, S., Sikarwar, S., Photo-catalytic degradation of toxic dye amaranth on $\mathrm{TiO}_{2} / \mathrm{UV}$ in aqueous suspensions, Mater. Sci. Eng. C 32 (2012) 12.

doi: https://doi.org/10.1016/j.msec.2011.08.018

9. Saleh, T. A., Gupta, V. K., Photo-catalyzed degradation of hazardous dye methyl orange by use of a composite catalyst consisting of multi-walled carbon nanotubes and titanium dioxide, J. Colloid Interface Sci. 371 (2012) 101 doi: https://doi.org/10.1016/j.jcis.2011.12.038

10. Karthikeyan, S., Gupta, V. K., Boopathy, R., Titus, A., Sekaran, G., A new approach for the degradation of high concentration of aromatic amine by heterocatalytic Fenton oxidation: Kinetic and spectroscopic studies, J. Mol. Liq. 173 (2012) 153 doi: https://doi.org/10.1016/j.molliq.2012.06.022

11. Saravanan, R., Sacari, E., Gracia, F., Khan, M. M., Mosquera, E., Gupta, V. K., Conducting PANI stimulated $\mathrm{ZnO}$ system for visible light photocatalytic degradation of coloured dyes, J. Mol. Liq. 221 (2016) 1029. doi: https://doi.org/10.1016/j.molliq.2016.06.074

12. Rajendran, S., Khan, M. M., Gracia, F., Qin, J., Gupta, V. $K$., Arumainathan, $S$., $\mathrm{Ce}^{3+}$-ion-induced visible-light photocatalytic degradation and electrochemical activity of $\mathrm{ZnO}$ / $\mathrm{CeO}_{2}$ nanocomposite, Scientific Reports 6 (2016) 31641. doi: https://doi.org/10.1038/srep31641

13. Saravanan, R., Gupta, V. K., Mosquera, E., Gracia, F., Narayanan, $V$., Stephen, A., Visible light induced degradation of methyl orange using $\beta-\mathrm{Ag} 0.333 \mathrm{~V}_{2} \mathrm{O}_{5}$ nanorod catalysts by facile thermal decomposition method, J. Saudi Chem. Soc. 19 (2015) 521. doi: https://doi.org/10.1016/j.jscs.2015.06.001

14. Saravanan, R., Gracia, F., Khan, M. M., Poornima, V., Gupta, V. K., Narayanan, V., Stephen, A., $\mathrm{ZnO} / \mathrm{CdO}$ nanocomposites for textile effluent degradation and electrochemical detection, J. Mol. Liq. 209 (2015) 374. doi: https://doi.org/10.1016/j.molliq.2015.05.040

15. Saravanan, R., Mansoob Khan, M., Gupta, V. K., Mosquera, E., Gracia, F., Narayanan, V., Stephen, A., ZnO/Ag/ $\mathrm{CdO}$ nanocomposite for visible light-induced photocatalytic degradation of industrial textile effluents, J. Colloid Interface Sci. 452 (2015) 126. doi: https://doi.org/10.1016/j.jcis.2015.04.035

16. Saravanan, R., Gupta, V. K., Narayanan, V., Stephen, A., Visible light degradation of textile effluent using novel catalyst $\mathrm{ZnO} / \gamma-\mathrm{Mn}_{2} \mathrm{O}_{3}$, J. Taiwan Inst. Chem. Eng. 45 (2014) 1910. doi: https://doi.org/10.1016/j.jtice.2013.12.021

17. Saravanan, R., Gupta, V. K., Mosquera, E., Gracia, F., Preparation and characterization of $\mathrm{V}_{2} \mathrm{O}_{5} / \mathrm{ZnO}$ nanocomposite system for photocatalytic application, J. Mol. Liq. 198 (2014) 409. doi: https://doi.org/10.1016/j.molliq.2014.07.030

18. Saravanan, R., Karthikeyan, N., Gupta, V. K., Thirumal, E., Thangadurai, P., Narayanan, V., Stephen, A., $\mathrm{ZnO} / \mathrm{Ag}$ nanocomposite: An efficient catalyst for degradation studies of textile effluents under visible light, Mater. Sci. Eng. C 33 (2013) 2235. doi: https://doi.org/10.1016/j.msec.2013.01.046

19. Saravanan, R., Gupta, V. K., Narayanan, V., Stephen, A., Comparative study on photocatalytic activity of $\mathrm{ZnO}$ prepared by different methods, J. Mol. Liq. 181 (2013) 133. doi: https://doi.org/10.1016/j.molliq.2013.02.023
20. Saravanan, R., Joicy, S., Gupta, V. K., Narayanan, V., Stephen, $A$., Visible light induced degradation of methylene blue using $\mathrm{CeO}_{2} / \mathrm{V}_{2} \mathrm{O}_{5}$ and $\mathrm{CeO}_{2} / \mathrm{CuO}$ catalysts, Mater. Sci. Eng. C 33 (2013) 4725. doi: https://doi.org/10.1016/j.msec.2013.07.034

21. Saravanan, R., Karthikeyan, S., Gupta, V. K., Sekaran, G., Narayanan, $V$., Stephen, A., Enhanced photocatalytic activity of $\mathrm{ZnO} / \mathrm{CuO}$ nanocomposite for the degradation of textile dye on visible light illumination, Mater. Sci. Eng. C 33 (2013) 91 . doi: https://doi.org/10.1016/j.msec.2012.08.011

22. Saravanan, R., Thirumal, E., Gupta, V. K., Narayanan, V., Stephen, A., The photocatalytic activity of $\mathrm{ZnO}$ prepared by simple thermal decomposition method at various temperatures, J. Mol. Liq. 177 (2013) 394. doi: https://doi.org/10.1016/j.molliq.2012.10.018

23. Saravanan, R., Gupta, V. K., Prakash, T., Narayanan, V., Stephen, A., Synthesis, characterization and photocatalytic activity of novel $\mathrm{Hg}$ doped $\mathrm{ZnO}$ nanorods prepared by thermal decomposition method, J. Mol. Liq. 178 (2013) 88. doi: https://doi.org/10.1016/j.molliq.2012.11.012

24. Gupta, V. K., Mittal, A., Jhare, D., Mittal, J., Batch and bulk removal of hazardous colouring agent Rose Bengal by adsorption techniques using bottom ash as adsorbent. RSC Adv. 2 (2012) 8381. doi: https://doi.org/10.1039/c2ra21351f

25. Somasundaran, P., Encyclopedia of Surface and Colloid Science, 2004 Update Supplement. CRC Press: 2004, Vol. 5.

26. Gupta, V., Srivastava, S., Mohan, D., Sharma, S., Design parameters for fixed bed reactors of activated carbon developed from fertilizer waste for the removal of some heavy metal ions, Waste Manage. (Oxford) 17 (1998) 517 doi: https://doi.org/10.1016/S0956-053X(97)10062-9

27. Saleh, T. A., Gupta, V. K., Column with CNT/magnesium oxide composite for lead(II) removal from water, Environ. Sci. Pollut. Res. 19 (2012) 1224. doi: https://doi.org/10.1007/s11356-011-0670-6

28. Mittal, A., Mittal, J., Malviya, A., Kaur, D., Gupta, V., Decoloration treatment of a hazardous triarylmethane dye, Light Green SF (Yellowish) by waste material adsorbents, J. Colloid Interface Sci. 342 (2010) 518. doi: https://doi.org/10.1016/j.jcis.2009.10.046

29. Mittal, A., Kaur, D., Malviya, A., Mittal, J., Gupta, V., Adsorption studies on the removal of coloring agent phenol red from wastewater using waste materials as adsorbents, J. Colloid Interface Sci. 337 (2009) 345. doi: https://doi.org/10.1016/j.jcis.2009.05.016

30. Mittal, A., Mittal, J., Malviya, A., Gupta, V., Adsorptive removal of hazardous anionic dye "Congo red" from wastewater using waste materials and recovery by desorption, J. Colloid Interface Sci. 340 (2009) 16. doi: https://doi.org/10.1016/j.jcis.2009.08.019

31. Gupta, V. K., Agarwal, S., Saleh, T. A., Synthesis and characterization of alumina-coated carbon nanotubes and their application for lead removal, J. Hazard. Mater. 185 (2011) 17. doi: https://doi.org/10.1016/j.jhazmat.2010.08.053

32. Gupta, V. K., Ali, I., Saleh, T. A., Nayak, A., Agarwal, S., Chemical treatment technologies for waste-water recycling-an overview, RSC Adv. 2 (2012) 6380. doi: https://doi.org/10.1039/c2ra20340e

33. Mittal, A., Mittal, J., Malviya, A., Gupta, V. K., Removal and recovery of Chrysoidine $\mathrm{Y}$ from aqueous solutions by waste materials, J. Colloid Interface Sci. 344 (2010) 497. doi: https://doi.org/10.1016/j.jcis.2010.01.007 
34. Gupta, V. K., Jain, R., Nayak, A., Agarwal, S., Shrivastava, $M$., Removal of the hazardous dye-Tartrazine by photodegradation on titanium dioxide surface, Mater. Sci. Eng. C 31 (2011) 1062.

doi: https://doi.org/10.1016/j.msec.2011.03.006

35. Gupta, V. K., Nayak, A., Cadmium removal and recovery from aqueous solutions by novel adsorbents prepared from orange peel and $\mathrm{Fe}_{2} \mathrm{O}_{3}$ nanoparticles, Chem. Eng. J. 180 (2012) 81 doi: https://doi.org/10.1016/j.cej.2011.11.006

36. Khani, H., Rofouei, M. K., Arab, P., Gupta, V. K., Vafaei, Z., Multi-walled carbon nanotubes-ionic liquid-carbon paste electrode as a super selectivity sensor: Application to potentiometric monitoring of mercury ion(II), J. Hazard. Mater. 183 (2010) 402. doi: https://doi.org/10.1016/j.jhazmat.2010.07.039

37. Jain, A. K., Gupta, V. K., Bhatnagar, A., Suhas, A comparative study of adsorbents prepared from industrial wastes for removal of dyes, Sep. Sci. Technol. 38 (2003) 463. doi: https://doi.org/10.1081/SS-120016585

38. Gupta, V. K., Nayak, A., Agarwal, S., Bioadsorbents for remediation of heavy metals: Current status and their future prospects, Environ. Eng. Res. 20 (2015) 1 doi: https://doi.org/10.4491/eer.2015.018

39. Saleh, T. A., Gupta, V. K., Processing methods, characteristics and adsorption behavior of tire derived carbons: A review, Adv. Colloid Interface Sci. 211 (2014) 93. doi: https://doi.org/10.1016/j.cis.2014.06.006

40. Gupta, V. K., Kumar, R., Nayak, A., Saleh, T. A., Barakat M. A., Adsorptive removal of dyes from aqueous solution onto carbon nanotubes: A review, Adv. Colloid Interface Sci. 193-194 (2013) 24.

doi: https://doi.org/10.1016/j.cis.2013.03.003

41. Devaraj, M., Saravanan, R., Deivasigamani, R., Gupta, V. $K$., Gracia, F., Jayadevan, S., Fabrication of novel shape $\mathrm{Cu}$ and $\mathrm{Cu} / \mathrm{Cu}_{2} \mathrm{O}$ nanoparticles modified electrode for the determination of dopamine and paracetamol, J. Mol. Liq. 221 (2016) 930. doi: https://doi.org/10.1016/j.molliq.2016.06.028

42. Saravanan, R., Khan, M. M., Gupta, V. K., Mosquera, E., Gracia, F., Narayanan, V., Stephen, A., $\mathrm{ZnO} / \mathrm{Ag} / \mathrm{Mn}_{2} \mathrm{O}_{3}$ nanocomposite for visible light-induced industrial textile effluent degradation, uric acid and ascorbic acid sensing and antimicrobial activity, RSC Adv. 5 (2015) 34645. doi: https://doi.org/10.1039/C5RA02557E

43. Gupta, V. K., Saleh, T. A., Sorption of pollutants by porous carbon, carbon nanotubes and fullerene- An overview, Environ. Sci. Pol. Res. 20 (2013) 2828. doi: https://doi.org/10.1007/s11356-013-1524-1

44. Ahmaruzzaman, M., Gupta, V. K., Rice husk and its ash as low-cost adsorbents in water and wastewater treatment, Ind. Eng. Chem. Res. 50 (2011) 13589. doi: https://doi.org/10.1021/ie201477c

45. Mohammadi, N., Khani, H., Gupta, V. K., Amereh, E., Agarwal, S., Adsorption process of methyl orange dye onto mesoporous carbon material-kinetic and thermodynamic studies, J. Colloid Interface Sci. 362 (2011) 457. doi: https://doi.org/10.1016/j.jcis.2011.06.067

46. Irdemez, Ş., Demircioğlu, N., Yildiz, Y. Ş., The effects of $\mathrm{pH}$ on phosphate removal from wastewater by electrocoagulation with iron plate electrodes, J. Hazard. Mater. 137 (2006) 1231. doi: https://doi.org/10.1016/j.jhazmat.2006.04.019

47. Saravanan, R., Prakash, T., Gupta, V. K., Stephen, A., Tailoring the electrical and dielectric properties of $\mathrm{ZnO}$ nanorods by substitution, J. Mol. Liq. 193 (2014) 160. doi: https://doi.org/10.1016/j.molliq.2013.12.029
48. Yoon, J., Amy, G., Chung, J., Sohn, J., Yoon, Y., Removal of toxic ions (chromate, arsenate, and perchlorate) using reverse osmosis, nanofiltration, and ultrafiltration membranes, Chemosphere 77 (2009) 228. doi: https://doi.org/10.1016/j.chemosphere.2009.07.028

49. Saleh, T. A., Gupta, V. K., Synthesis and characterization of alumina nano-particles polyamide membrane with enhanced flux rejection performance, Sep. Purif. Technol. 89 (2012) 245 . doi: https://doi.org/10.1016/j.seppur.2012.01.039

50. Pillay, K., Cukrowska, E. M., Coville, N. J., Multi-walled carbon nanotubes as adsorbents for the removal of parts per billion levels of hexavalent chromium from aqueous solution, J. Hazard. Mater. 166 (2009) 1067. doi: https://doi.org/10.1016/j.jhazmat.2008.12.011

51. Rajput, S., Pittman Jr, C. U., Mohan, D., Magnetic magnetite $\left(\mathrm{Fe}_{3} \mathrm{O}_{4}\right)$ nanoparticle synthesis and applications for lead $\left(\mathrm{Pb}^{2+}\right)$ and chromium $\left(\mathrm{Cr}^{6+}\right)$ removal from water, J. Colloid Interface Sci. 468 (2016) 334. doi: https://doi.org/10.1016/j.jcis.2015.12.008

52. Fu, F., Ma, J., Xie, L., Tang, B., Han, W., Lin, S., Chromium removal using resin supported nanoscale zero-valent iron, J. Environ. Manag. 128 (2013) 822 doi: https://doi.org/10.1016/j.jenvman.2013.06.044

53. da Fonseca, M. G., de Oliveira, M. M., Arakaki, L. N. H., Removal of cadmium, zinc, manganese and chromium cations from aqueous solution by a clay mineral, J. Hazard. Mater. 137 (2006) 288 doi: https://doi.org/10.1016/j.jhazmat.2006.02.001

54. Al-Othman, Z. A., Ali, R., Naushad, M., Hexavalent chromium removal from aqueous medium by activated carbon prepared from peanut shell: Adsorption kinetics, equilibrium and thermodynamic studies, Chem. Eng. J. 184 (2012) 238. doi: https://doi.org/10.1016/j.cej.2012.01.048

55. Baniamerian, M. J., Moradi, S. E., Noori, A., Salahi, H., The effect of surface modification on heavy metal ion removal from water by carbon nanoporous adsorbent, Appl. Surf. Sci. 256 (2009) 1347. doi: https://doi.org/10.1016/j.apsusc.2009.08.106

56. Salimian, M., Ivanov, M., Deepak, F. L., Petrovykh, D. Y., Bdikin, I., Ferro, M., Kholkin, A., Titus, E., Goncalves, G., Synthesis and characterization of reduced graphene oxide/ spiky nickel nanocomposite for nanoelectronic applications, J. Mater. Chem. C 3 (2015) 11516. doi: https://doi.org/10.1039/C5TC02619A

57. Xu, B., Yue, S., Sui, Z., Zhang, X., Hou, S., Cao, G., Yang, $Y$., What is the choice for supercapacitors: graphene or graphene oxide?, Energy Environ Sci. 4 (2011) 2826. doi: https://doi.org/10.1039/c1ee01198g

58. Basu, S., Bhattacharyya, P., Recent developments on graphene and graphene oxide based solid state gas sensors, Sens. Actuators B Chem. 173 (2012) 1. doi: https://doi.org/10.1016/j.snb.2012.07.092

59. Wang, L., Lee, K., Sun, Y.-Y., Lucking, M., Chen, Z., Zhao, J. J., Zhang, S. B., Graphene oxide as an ideal substrate for hydrogen storage, ACS Nano 3 (2009) 2995. doi: https://doi.org/10.1021/nn900667s

60. Liu, J., Cui, L., Losic, D., Graphene and graphene oxide as new nanocarriers for drug delivery applications, Acta Biomater. 9 (2013) 9243. doi: https://doi.org/10.1016/j.actbio.2013.08.016

61. Alvand, M., Shemirani, F., Preconcentration of trace cadmium ion using magnetic graphene nanoparticles as an efficient adsorbent, Microchim. Acta 181 (2014) 181. doi: https://doi.org/10.1007/s00604-013-1094-4 
62. Plechkova, N. V., Seddon, K. R., Applications of ionic liquids in the chemical industry, Chem. Soc. Rev. 37 (2008) 123. doi: https://doi.org/10.1039/B006677J

63. Nasrollahpour, A., Moradi, S. E., Baniamerian, M. J., Vortex-assisted dispersive solid-phase microextraction using ionic liquid-modified metal-organic frameworks of PAHs from environmental water, vegetable, and fruit juice samples, Food Anal. Methods 10 (2017) 2815. doi: https://doi.org/10.1007/s12161-017-0843-0

64. Nasrollahpour, A., Moradi, S. E., Hexavalent chromium removal from water by ionic liquid modified metal-organic frameworks adsorbent, Microporous Mesoporous Mater. 243 (2017) 47. doi: https://doi.org/10.1016/j.micromeso.2017.02.006

65. Wang, C., Chen, Y., Zhuo, K., Wang, J., Simultaneous reduction and surface functionalization of graphene oxide via an ionic liquid for electrochemical sensors, Chem. Commun. 49 (2013) 3336.

doi: https://doi.org/10.1039/c3cc40507a
66. Zhou, J., Wang, Y., Wang, J., Qiao, W., Long, D., Ling, L., Effective removal of hexavalent chromium from aqueous solutions by adsorption on mesoporous carbon microspheres, J. Colloid Interface Sci. 462 (2016) 200. doi: https://doi.org/10.1016/j.jcis.2015.10.001

67. Zeng, Y., Woo, H., Lee, G., Park, J., Removal of chromate from water using surfactant modified Pohang clinoptilolite and Haruna chabazite, Desalination 257 (2010) 102. doi: https://doi.org/10.1016/j.desal.2010.02.039

68. Yao, X., Deng, S., Wu, R., Hong, S., Wang, B., Huang, J., Wang, $Y$., $Y u, G$., Highly efficient removal of hexavalent chromium from electroplating wastewater using aminated wheat straw, RSC Advances 6 (2016) 8797. doi: https://doi.org/10.1039/C5RA24508G

69. Qu, Y., Zhang, X., Xu, J., Zhang, W., Guo, Y., Removal of hexavalent chromium from wastewater using magnetotactic bacteria, Sep. Purif. Technol. 136 (2014) 10. doi: https://doi.org/10.1016/j.seppur.2014.07.054 